\title{
Abordando a Termologia na Construção de um Aquecedor Solar usando a Pedagogia de Projetos
}

\author{
Franciele Biella Sá Monteiro ${ }^{1}$, Mônica Guimarães Fonseca ${ }^{2}$, Daniela Fontana Almenara ${ }^{3}$ \\ Eliane Silva Leite ${ }^{4}$, Walter Trennepohl Júnior ${ }^{5}$ \\ 1, 2, 3, 4, 5 Universidade Federal de Rondônia (UNIR)
}

Palavras-Chave: Termologia, pedagogia de projetos, aprendizagem significativa.

\section{Introdução}

Em vista da dificuldade encontrada atualmente em tornar as aulas e conteúdos trabalhados mais atrativos e significativos para os estudantes, o presente trabalho pretende desenvolver um projeto para construção de um aquecedor solar utilizando a pedagogia de projetos. Prado (2001) enaltece em seu artigo a importância da pedagogia de projetos, no que diz respeito a identificar as estratégias envolvidas para desenvolver no aluno competências e habilidades. Essas estratégias são diferentes maneiras de se abordar um conteúdo, que podem ser: aulas expositivas, exposição de vídeos, realização de experimentos e criação de mapas conceituais. A aprendizagem significativa de David Ausubel é o embasamento para a aplicação deste produto, direcionado para turmas de $9^{\circ}$ ano do ensino fundamental. Para Ausubel, o que mais influencia o processo de ensinoaprendizagem é o que o educando já sabe (MOREIRA, M. A; OSTERMANN, F, 1999), desse modo, identificando os conhecimentos prévios, subsunçores, dos estudantes e preparando as aulas baseadas nessa informação, o estudante será capaz de ancorar novos conhecimentos nesses subsunçores.

Nesse contexto, a pedagogia de projetos envolve três aspectos a se considerar: primeiro, os objetivos, as intenções e ações devem ser claras, que neste caso é o aprendizado de termologia através de aulas variadas; segundo, é preciso incorporar novas tecnologias para enriquecer e agregar avanços e, terceiro, são os conceitos das áreas de conhecimentos relacionados com a problemática em estudo (PRADO, 2001). Vale ressaltar que é de suma importância o preparo do professor em lidar com esta prática pedagógica, senão a ação é em vão.

A experimentação é uma estratégia capaz de aproximar o conteúdo à prática, propicia a participação ativa do estudante, fazendo com que se sintam desafiados ao construir um experimento (BRASIL, 1997). Além disso, interagem e trocam experiências e, nesse processo de elaboração de estratégias para resolver os desafios, o próprio estudante constrói seu conhecimento. Desse modo, a pedagogia de projetos estimula o estudante a pesquisar para responder seus questionamentos, proporcionando uma competição sadia na construção, neste caso, de um aquecedor mais eficiente e barato.

Em vista disso, organizar e trabalhar os conteúdos em forma de projetos promove a utilização de diferentes ferramentas, além de esta representar uma metodologia que pode despertar o interesse dos estudantes, tornando-os mais participativos e, em consequência, o processo de ensino-aprendizagem pode se tornar mais atrativo e eficiente.

Logo, com a aplicação da metodologia supracitada, os estudantes terão a oportunidade de participar mais ativamente da construção do conhecimento. A interação promovida pela realização de experimentos e pelo trabalho em grupo, por meio de projetos, oportuniza uma troca entre estudantes de diferentes níveis, bem como promove o professor ao patamar de mediador das situações de ensino-aprendizagem. As reflexões oportunizadas após cada momento vivenciado nas aulas e mediadas pelo professor constituirão em embasamento para a construção do conhecimento individual e coletivo.

Dessa forma, o trabalho pretende despertar nos estudantes interesse nos conteúdos de termologia, incentivando, desse modo, a autonomia em pesquisar e descobrir e, ainda, melhorar o nível de instrução também de professores, fornecendo a estes subsídios para que o processo de ensino-aprendizagem ocorra satisfatoriamente dentro do conteúdo proposto. 


\section{Metodologia e Material}

Os materiais didáticos a serem utilizados para desenvolvimento do trabalho serão: filmes extraídos da internet, textos relacionados ao assunto de termologia em livros ou na internet e simulações on line no Phet, enquanto que os materiais para a construção do aquecedor serão preferencialmente materiais de baixo custo.

A aplicação da sequência didática, embasada na teoria construtivista de Ausubel, se dará durante o $3^{\circ}$ bimestre letivo, terá a duração de 10 aulas, e contará inicialmente com a execução de um pré-teste para a avaliação dos pré-conhecimentos, aula expositiva com o auxílio de vídeos, simulações no Phet, leitura de textos diversos (especialmente do GREF - Grupo de Reelaboração do Ensino da Física) em GREF (1998) e experimentos de termologia. Durante esta fase, que terá a duração de 5 aulas, os alunos serão estimulados a escrever pequenos textos e elaborar mapas conceituais relacionados ao tema abordado. Na fase seguinte, que durará 4 aulas, os alunos serão divididos em grupos para planejarem e construírem o aquecedor de água solar, isto é, um dispositivo que, mediante o uso da energia solar, consiga variar a temperatura de uma mesma quantidade de água no menor intervalo de tempo e com o menor custo de fabricação. No final da execução do projeto será aplicado um pós-teste para avaliar o processo de ensino-aprendizagem dos alunos.

\section{Resultados Esperados}

Espera-se que os estudantes da turma em que será aplicada esta sequência didática consigam entender e definir corretamente os conceitos de calor, temperatura, convecção, condução, irradiação e dilatação térmica. Para medir o desempenho desta metodologia serão comparados os pré-testes com os pós-testes.

Além de melhor desenvolvimento teórico do conteúdo em questão, espera-se também que esta prática promova um maior envolvimento e participação dos estudantes nas aulas do próximo bimestre, fato que será comprovado ou não através da observação do comportamento dos alunos antes e depois da aplicação desta sequência didática pelo professor.

\section{Referências}

BRASIL. Secretaria da Educação Fundamental. Parâmetros curriculares nacionais: ciências naturais. Brasília: MEC/SEF, 1997.

GREF - Grupo de Reelaboração do Ensino da Física. Termo 1, 2, 3 e 4. Instituto de Física da USP. Junho, 1998.

MOREIRA, M. A.; OSTERMANN, F. Teorias Construtivistas. Série Textos de Apoio ao Professor. Porto Alegre: IFURGS, 1999.

PRADO, M. E. B. B. Articulando saberes e transformando a prática. Boletim do Salto para o Futuro. Série Tecnologia e Currículo, TV Escola. Brasília: Secretaria de Educação a Distância SEED. Ministério da Educação, 2001. Disponível em: <http:WWW.tvebrasil.com.br>. Acesso em: 10 maio 2019. 